\title{
PENERAPAN METODE TOTAL QUALITY MANAGEMENT DALAM ORGANISASI PESANTREN
}

\section{UMI MASRUROH}

UNUJA, Jl. K. H. Zaini Mun'im Paiton Probolinggo

e-mail: umimasruroh0410@gmail.com

\begin{abstract}
ABSTRAK
Pesantren sebagai local genius masih tetap diakui oleh existensi dan kontribusinya dalam membangun suatu bangsa dan negara Indonesia, khususnya dalam meberikan warna pendidikan Islam di Indonesia. Akan tetapi, dalam menghadapi tantangan dunia global dengan perkembangan teknologi dan informasi yang begitu dahsyat, pesantren harus segera berbenah diri dan mengambil langkah antisipatif. Pola-pola manajemen pesantren sudah seharusnya mulai dirubah ke arah manajemen modern yang lebih mengedepankan kualitas dan kepuasan pelanggan, yang lebih dikenal dengan Total Quality Manajemen (TQM). Penelitian ini bertujuan menjelaskan konsep Total Quality Manajemen dalam kasus Pesantren Nurul Jadid Jawa Timur, dan dapat dijadikan acuan bagi pesantren-pesantren lain dalam menyusun dan mengambil kebijakan organisasi manajemen lembaganya yang berujung pada pemenuhan tuntutan kualitas dan kepuasan masyarakat. Metode yang digunakan dalam penelitian ini adalah metode penelitian kualitatif. Penelitian ini dirancang dengan menggunakan rancangan studi kasus. Rancangan studi studi kasus merupakan pengujian secara rinci terhadap satu latar atau satu orang subjek atau satu tempat penyimpanan dokumen atau satu peristiwa tertentu. Hasil penelitian ini menyimpulkan bahwa menurut pandangan pengelola pesantren Nurul Jadid untuk mengikuti konsep berpikir TQM, maka manajemen Pesantren harus memandang bahwa proses organisasi adalah suatu wadahuntuk mencapai tujuan bersama. Pondok Pesantren Nurul Jadid melakukan modernisasi dalam pengelolaan pondok sebagai upaya mengantisipasi kemajuan organisasi dengan melakukan pemantapan internal dan melakukan penyesuaian visi dan misi organisasi ke arah perubahan global. Dalam
\end{abstract}


menentukan segala kebijakan terkait peningktan mutu pesantren, pengelola pesantren selalu melibatkan masyarakat dalam memberikan masukan.

\section{Kata Kunci : Total Quality Management, Pesantren}

\section{PENDAHULUAN}

Organisasi pesantren merupakan sebuah kelompok yang terdapat dalam pesantren. Dimana anggota dalam kelompok tersebut ialah beberapa santri yang menetap dalam pesatren tersebut, untuk membantu seorang pemimpin yang biasa disebut kiai dalam mencapai tujuan-tujuan yang telah direncanakan. Organisasi dalam pesantren ini mempunyai dua jenis yakni informal dan formal, karena dalam sebuah pesantren bukan hanya berdiri suatu lembaga pendidikan formal saja namun dalam pesantren juga terdapat berbagai lembaga yang non formal. Sehingga dalam lembaga-lembaga tersebut didirikan berbagai organisasi. Sebuah organisasi pesantren disisi ia ingin mencapai tujuan yang telah ditetapkan juga mencoba untuk menjadikan organisasi tersebut menjadi organisasi yang berkualitas dan bermutu.

Mutu merupakan sesuatu yang abstrak namun sangat diharapkan oleh setiap kalangan dalam berbagai kegiatan dalam sebuah organisasi. Banyak lembaga yang berkompetisi dalam menjadikan sebuah organisasi terpadu. Sebagaimana diinterpretasikan oleh ISO 9000, yang merupakan perpaduan antara sifat-sifat dan karakteristik yang menentukan sampai beraa jauh organisasi tersebut dapat mencapai suatu tujuan. Sedangkan organisasi yang berkualitas yang dibentuk oleh pondok pesantren dimana dalam organisasi pesantren tersebut terbentuk organisasi yang berkualitas.

Peningkatan mutu tidak hanya meliputi input (masukan) namun juga proses output (lulusan). Mutu input meliputi atasan, bawahan, struktur, deskripsi tugas, visi, misi, tujuan, sasaran, dan kebijakan. Mutu proses disini meliputi pembuatan keputusan, pengelolaan, program, dan evaluasi. Sedangkan mutu output meliputi hasil kerja suatu organisasi, ukuran yang digunakan, kefektifan, efesiensi, produktifitas, inovasi dan kreatifitas, kualitas organisasi, disiplin, dan semangat. Adapun komponen mutu organisasi meliputi anggota (motivasi), 
pemimpin (profesional dan kerja sama) serta masyarakat yang dapat berpartisipasi dalam mengembangkan organisasi tersebut.

Artikel ini akan mengupas pengertian organisasi, pengertian pesantren, apa saja metode total quality manajemen, dan bagaimana penerapan metode quality manajemen dalam organisasi pesantren. ${ }^{1}$

\section{PENGERTIAN ORGANISASI}

Secara etimologi organisasi berasal dari bahasa latin "organum” yang berarti "alat". Adapun kata organisasi dalam bahasa inggris "organize”, berarti "mengorganisasikan" yang menunjukkan suatu usaha untuk mencapai sesuatu. Organisasi yang merupakan fungsi manajemen telah banyak didefinisikan oleh para ahli, seperti Gibson yang mengartikan organisasi sebagai wadah yang mungkin dapat digunakan masyarakat untuk meraih hasil, yang sebelumnya belum tercapai oleh masing-masing individu. Robins mendefinisikan organisasi sebagai kesatuan sosial yang dikoordinasi dengan cara sadar dengan batasan yang relatif dapat diidentifikasi, yang bekerja secara relatif terus-menerus untuk mencapai suatu tujuan bersama. Sondang P. Sigian mengemukakan bahwa "organisasi adalah setiap bentuk persekutuan yang terdiri atas dua orang atau lebih yang bekerja sama dan terikat dalam tujuan yang telah ditentukan bersama baik dalam sebuah persekutuan bersama atau beberapa orang yang biasa disebut atasan dan seseorag lainnya disebut bawahan." Prajudi Atmosudirjo mengemukakan bahwa organisasi adalah "sebuah struktur tata pembagian kerja dan hubungan kerja antara sekelompok orang-orang yang memegang posisi tertentu untuk bersama-sama dalam mencapai tujuan tertentu." Organisasi diartikan sebagai kumpulan orang dengan sistem kerja sama untuk mencapai tujuan bersama. ${ }^{2}$

Hoy dan Miskel yang telah menelusuri kajian organisasi dalam tiga pandangan, yaitu pandangan rasional organisasi merupakan instrumen formal guna mecapai tujuan organisasi dan struktur yang merupakan hal yang paling

\footnotetext{
${ }^{1}$ Cakrawala Pendidikan, Juni 2005, Th. XXIV, No. 2

2 Nanang Fattah, Landasan Manajemen Pendidikan, (Bandung: PT REMAJA ROSDAKARYA, 2011).
} 
penting dalam organisasi. Pandangan natural, organisasi dipandang sebagai suatu kelompok khusus dengan tujuan pertahanan dan orang-orang merupakan asek yang paling penting didalamnya. Sedangkan dalam pandangan open system adalah organisasi dipandang sebagai suatu yang potensial dalam menggabungkan antara pandangan rasional dan natural dalam satu kerangka dan memberikan suatu pandangan yang lengkap.

Beberapa pengertian di atas menunjukkan bahwa organisasi adalah sebuah wadah, tempat ataupun sistem untuk melakukan kegiatan bersama agar dapat mencapai tujuan yang diinginkan. Adapun pengorganisasian (organizing) adalah suatu proses pembentukan wadah dan penyusuna anggota dalam struktur untuk mencapai tujuan organisasi. Terdapat beberapa unsur untuk membentuk suatu organisasi, yaitu: 1) adanya tujuan bersama, organisasi biasanya mensyaratkan sesuatu yang diinginkan dengan rumusan visi, misi, target dan tujuan. Tujuan nilah yang dapat menyatukan berbagai unsur yang terdapat dalam organisasi. 2) adanya kerja sama antara dua orang atau lebih, organisasi terbentuk karena adanya kerja sama untuk mencapai tujuan bersama. 3) Adanya pembagian tugas. Agar sebuah organisasi dapat efektif, efesien, dan produktif maka diperlukan pembagian tugas. 4) Adanya kehendak untuk bekerja sama. Setiap anggota organisasi harus mempunyai kemauan untuk bekerja sama, sehingga dapat mencapai tujuan bersama.

Dalam organisasi terdapat dua jenis organisasi, yakni: a) organisasi formal. Organisasi formal adalah Sebuah organisasi yang dicirikan oleh struktur organisasi. Adanya struktur organisasi dapat menjadi pembeda utama antara organisasi formal dan informal. Struktur organisasi formal menyediakan penugasan kewajiban dan tanggung jawab kepada para personel serta membangun hubungan tertentu dengan orang-orang dari berbagai kedudukan. Contoh organisasi formal, seperti lembaga pendidikan (SD/MI, SMP/MTS, SMU/SMA). Dalam struktur organisasi formal selalu memerhatikan unsur-unsur administrasi, diantaranya; Kedudukan setiap orang yang digambarkan dalam setiap struktur, hierarki kekuasaan yang digambarkan sebagai suatu rangkaian hubungan antara satu orang dengan orang lain dalam suatu organisasi, serta kedudukan garis dan 
staf yang menegaskan struktur dalam mengambil keputusan, jalan permohonan dan saluran komunikasi resmi untuk melapokan informasi dan mengeluarkan intruksi perintah dan petunjuk pelaksana. Biasanya bentuk organisasi formal dapat berbentuk piramidal, mendatar, atau melingkar. b) organisasi informal. Untuk mendefinisikan organisasi informal sangat sulit, namun keberadaan dan karakteristiknya sangat biasa ditemukan dalam masyarakat kita. Karakterstik yang ada dalam organisasi informal adalah adanya norma perilaku yang meruapakan standar perilaku untuk diharapkan menjadi perilaku bersama yang telah ditetapkan oleh kelompok dam sebuah kesepakatan sehingga sanksinya pun sanksi sosial. Norma perilaku dalam organisasi informal tidak tertulis dalam organisasi formal, akan tetapi sudah menjadi kesepakatan antara orang-orang dan anggota kelompok suatu organisasi. Dengan adanya karakteristik Tekenan untuk menyesuaikan diri yang akan muncul apabila seseorang akan bergabung dengan organisasi informal. Tergabungnya seseorang dalam organisasi infirmal bukan hanya dalam bentuk fisik akan tetapi melibatkan sosio-emosionalnya, sehingga menjadi satu kesatuan dan mempunyai rasa saling memilki di antara anggota. Serta dengan adanya karakteristik kepemimpinan informal, yang dalam organisasi informal akan menjadi komponen yang sangat kuat sehingga dapat mempengaruhi orang-orang di dalam organisasi, bahkan dapat memungkinkan melebihi kepemimpinan dalam organisasi formal. Pemimpin informal muncul dari kelompok dan membimbing serta mengarhkan melalui jalur persuasi dan pengaruh. Kepemimpinan dalam bentuk ini dapat dilihat dalam kepemimpinan adat suku tertentu, kelompok, agama, dan lain sebagainya. ${ }^{3}$

\section{PENGERTIAN PESANTREN}

Pesantren berasal dari kata santri yang mendapat tambahan pe- dan -an, dimana kata santri memilki arti murid atau peserta didik. Sedangkan istilah pondok dalam kata "pondok pesantren" berasal dari kosa kata bahasa arab yakni funduuq yang berarti penginapan. Seorang pemuka yang bernama Zamakhsyari Dhofier memberi pendapat bahwa pesantren adalah sebuah tempat pendidikan tradisional dimana para siswa yang biasa disebut dengan sebutan santri tinggal

\footnotetext{
${ }^{3}$ Imam Machali, dkk, The Handbook of Education Management, (Jakarta: PrenadamediaGroup, 2016), 63-66
} 
bersama dan belajar di bawah bimbingan seorang guru yang biasa disebut kiai, serta mempunyai asrama atau tempat menginap santri. Pesantren tidak hanya menyediakan tempat menginap, namun pesantren juga menyeidiakan beberapa tempat, seperti: masjid untuk beribadah, ruang untuk belajar, dan berbagai tempat untuk kegiatan keagamaan lainnya. Santri yang berada di pesantren biasanya tempat tersebut dikelilingi tembok agar dapat mengawasi keluar masuknya para santri sesuai dengan peraturan yang telah diberlakukan.

Terdapat pula seorang penulis buku yang berjudul "bilik-bilik pesantren" mengemukakan bahwa, pondok pesantren merupakan dua istilah yang digabung menjadi satu serta memiliki satu pengertian. Kata pesantren menurut pengertian dasarnya adalah sebuah tempat belajar untuk para santri, sedangkan pondok berarti rumah atau tempat tinggal sederhana yang biasanya terbuat dari bambu. Di samping itu, kata pondok berasal dari kata funduq yang bermakna asrama atau hotel, namun terdapat beberapa perbedaan nama dalam berbagai daerah tertentu, seperti di aceh yang menggunakan istilah pondok dengan sebutan dayah, rangkang atau menuansa. Sedangkan di minangkabau menggunakan istilah yang biasa disebut dengan surau.

Pendapat lain tentang pesantren yang dikemukakan oleh Sudjono Prasodjo, bahwa pesantren juga dapat dipahami sebagai lembaga pendidikan dan tempat pembelajaran agama, dimana seorang kiai mengajarkan ilmu yang berkaitan dengan agama Islam terhadap para santri berdasarkan ijma', qiyas dan beberapa kitab yang telah ditulis dalam bahasa arab oleh para ulama abad pertengahan, dan para santri tersebut biasanya tinggal atau menetap di lingkungan pondok (asrama) yang ada pada pesantren tersebut.

Dari berbagai pengertian di atas dapat disimpulkan bahwa, pesantren adalah sebuah tempat lembaga pendidikan yang biasanya dipimpin oleh seorang kiai yang didalamnya diajarkan sebuah ilmu agama Islam dengan landasan AlQur'an, Hadist, dan ijma', serta sebuah tempat untuk menetapnya para santri. 
7 | Penerapan Metode Total Quality Management (TQM) Dalam Organisasi Pesantren

Dimana dalam tempat tersebut, dapat melatih para santri untuk belajar hidup mandiri sekaligus dapat meningkatkan hubungan dengan Allah SWT. ${ }^{4}$

\section{PENERAPAN METODE TOTAL QUALITY MANAGEMENT PADA ORGANISASI PESANTREN}

Total quality management bukanlah suatu pengendalian mutu (quality control) yang merupakan pengendalian mutu setelah proses produksi (after-theevent process). Namun TQM selalu terpusat pada kepuasan pelanggan (customer satisfaction) dan mengadakan suatu pengendalian mutu sejak awal.

Untuk dapat menerapkan $T Q M$ pada organisasi pesantren, lebih dahulu ditinjau utama organisasi tersebut menerapkan TQM. Tujuan utama organisasi pesantren yang menerapkan filosofi $T Q M$ adalah memenuhi kebutuhan dan keinginan pelanggan. Organisasi yang baik yang haus menciptakan dan memelihara kedekatan hubungan dengan pelanggan. Kualitas harus sesuia dengan kebutuhan dan harapan pelanggan. Kualitas adalah sesuatu yang diinginkan dan diharapkan oleh pelanggan, baik pelanggan internal (yaitu semua pihak yang berada dalam lingkungan pesantren) maupun eksternal (yaitu semua pihak yang berada di luar lingkungan pesantren, seperti masyarakat).

Banyak orang mempelajari bagaimana menggunakan metode TQM dalam organisasi. Dalam menerapkan manajemen yang terpadu maka terdapat beberapa metode yang telah dipaparkan oleh beberapa ilmuwan sebagai berikut:

1. Metode Joseph M. Juran

Juran adalah seorang ilmuwan yang ahli dalam bidang manajemen kualitas dan ia juga mempunyai sebuah kontribusi penting dalam perkembangan dan kemajuan quality. Sehingga juran mendefinisikan kualitas sebagai sesuainya suatu barang atau jasa dengan apa yang telah diharapkan oleh sang pemilik. Juran memilki tiga metode dasar yang paling terkenal, yaitu Juran's Basic Steps to Progress dimana metode dasar ini dapat digunakan oleh sebuah perusahaan untuk mencapai kualitas tingkat dunia. Juran menyakini bahwa meode ini mempunyai titik yang berhubungan antara kualitas dan daya saing. Maksud dari ketiga metode

\footnotetext{
${ }^{4}$ Mizan Akbar, Penerapan TQM, Juli 2017
} 
8 Penerapan Metode Total Quality Management (TQM) Dalam Organisasi Pesantren

tersebut, adalah: a) Mencapai suatu perbaikan yang sudah terstruktur dan berkesinambungan. b) Mengadakan program pelatihan. c) Membentuk komitmen.

\section{William Edward Deming}

Menurut Deming kesuksesan dalam memimpin sebuah revolusi di negara Jepang, yaitu dengan memperkenalkan penggunaan teknik pemecahan suatu masalah dan sebuah pengendali proses statistik yang biasanya disebut dengan SPC (Statistical Proses Control). Salah satu metode yang paling terkenal adalah siklus deming.

Siklus deming adalah sebuah model yang dikembangkan oleh W. Edward Deming yang terdiri dari empat kompenen utama secara berurutan yang biasa dikenal dengan siklus PDCA (Plan-Do-Check-Art). Terdapat beberapa penjelasan dari siklus PDCA tersebut, yakni: 1) Plan. Langkah ini merupakan sebuah metode setelah dilakukannya pengujian terhadap ide perbaikan masalah. Dalam hal ini, rencana perbaikan disusun berdasarkan tehnik bertanya berdasarkan prinsip 5-W (what, why, who, when, dan where) dan $1 \mathrm{H}$ (how), yang dibuat secara rinci dan jelas serta menetapkan target capaian. Untuk menetapkan sebuah target maka diharuskan pula untuk memperhatikan prinsip SMART (specific, measurable, attainable, dan time). 2) Do. Rencana yang telah disusun diimplementasikan secara bertahap, mulai dari rencana yang berskala kecil dengan pembagian tugas yang merata sesuai dengan kemampuan setiap personil. Selama dalam melaksanakan rencana tersebut harus ada pengendalian agar seluruh rencana dapat dilaksanakan sebaik mungkin sehingga sasaran yang diinginkan dapat tercapai. 3) Check atau Study. Memeriksa atau meniliti hasil yang merujuk pada penetapan apakah jalur pelaksanaannya sesuai dengan rencana serta memantau kemajuan perbaikan yang telah direncanakan. Alat yang biasa digunakan untuk meniliti atau memeriksa hasil adalah pareto diagram, histogram, dan diagram kontrol. 4) Action. Penyesuaian dilakukan bila perlu saja, yang berdasar pada hasil analisis di atas. Penyesuaian berkaitan dengan standarisasi baru untuk menghindari timbulnya masalah yang sama atau menetapkan sasaran yang baru untuk perbaikan selanjutnya. 


\section{Metode Philip B. Ayard Crosby}

Crosby menyatakan bahwa dalil-dalil manajemen diantaranya adalah mendefinisikan bawa kualitas dan persyaratan merupakan suatu hal yang sama, sebuah metode zero defects merupakan standar yang perlu digunakan dan price of non conformance (biaya ketidaksesuaian produk) menjadi suatu ukuran mutu.

Karena telah dipaparkan sebelumnya bagaiman cara kita untuk menerapkan metode tersebut maka langkah pertama dalam organisasi yang telah dipaparkan oleh Josph M. Juran bahwa untuk membentuk suatu organisasi yang bermutu adalah dengan mencapai sesuatu yang telah terstruktur dan berkesinambungan. Dalam hal ini, maka kita harus mencapai tujuan yang telah disusun bersama dalam suatu organisasi. Jika tujuan tersebut telah tercapai maka kita harus mengadakan sebuah program pelatihan agar tujuan tersebut tidak hanya tercapai namun juga terealisasikan dengan benar, dan dengan terlaksananya pelatihan tersebut maka bentuklah suatu komitmen antara satu anggota dan anggota lainnya, agar organisasi tersebut dapat menjadi organisasi yang bermutu.

Ciri-ciri lain organisasi pesantren yang bermutu adalah sangat erat kaitannya dengan adanya keterlibatan masyarakat secara totalitas di dalamnya. Baik masyarakat internal dan ekternal yang selalu menyelenggarakan musyawarah secara mingguan. Mutu menuntut adanya komitmen antar anggota agar dapat mencapai tujuan yang telah ditentukan. Sehingga organisasi tersebut dapat menjadi organisasi yang terpadu. ${ }^{5}$

\section{ANALISA PENERAPAN METODE TQM}

Metode TQM yang telah diterapkan oleh madrasah diniyah Nurul Jadid, yaitu metode TQM PDCA (Plan-Do-Check-Art). Dalam menerapkan metode ini terhadap organisasi madrasah diniyah nurul jadid agar menjadi sebuah organisasi yang bermutu, yaitu dengan cara merencanakan, melakukan, teliti, dan tampilkan. Berdasarkan hasil analisa disini yang telah diterapkan dalam organisasi madrasah diniyah Nurul Jadid yakni sebagai berikut:

\footnotetext{
${ }^{5} \mathrm{http} /$ pengertian,karakteristik,metode,manfaatTQM;byMuchlisinRiadi,November 2017. (Lihat juga: Hasan Baharun, Manajemen Mutu Pendidikan, (Tulungagung: Akademia Pustaka, 2017), 75-85)
} 
1. Perencanaan organisasi MDNJ

\begin{tabular}{|c|l|c|}
\hline Waktu & \multicolumn{1}{|c|}{ program } & \multicolumn{1}{|c|}{ Penjab } \\
\hline $07: 20$ & $\begin{array}{l}\text { Pembacaan do'a bersama } \\
\text { dilapangan SMANJ }\end{array}$ & OSIM MDNJ \\
\hline $07: 30$ & $\begin{array}{l}\text { Pengontrolan atribut siswi } \\
\text { MDNJ }\end{array}$ & OSIM MDNJ \\
\hline $07: 35$ & $\begin{array}{l}\text { Penyangsiyan bagi siswi yang } \\
\text { telat hadir }\end{array}$ & OSIM MDNJ \\
\hline
\end{tabular}

Dalam hal ini, dapat juga rencana perbaikan disusun berdasarkan tehnik bertanya berdasarkan prinsip 5-W (what, why, who, when, dan where) dan $1 \mathrm{H}$ (how).

\begin{tabular}{|c|c|c|c|c|c|}
\hline What & Why & Who & when & where & how \\
\hline $\begin{array}{l}\text { Pembacaan } \\
\text { do'a bersama }\end{array}$ & $\begin{array}{l}\text { Agar seluruh } \\
\text { siswi } \\
\text { mendapatkan } \\
\text { kemudahan } \\
\text { dalam belajar }\end{array}$ & $\begin{array}{l}\text { Siswi } \\
\text { Madrasah } \\
\text { Diniyah } \\
\text { Nurul } \\
\text { Jadid }\end{array}$ & $\begin{array}{l}10 \text { menit } \\
\text { sebelum } \\
\text { pelajara } \\
\text { n dimulai }\end{array}$ & $\begin{array}{l}\text { Dilapangan } \\
\text { SMA Nurul } \\
\text { Jadid }\end{array}$ & $\begin{array}{l}\text { Pembacaan } \\
\text { do'a yang } \\
\text { dipimpin } \\
\text { lansung } \\
\text { oleh bagian } \\
\text { OSIM yang } \\
\text { telah } \\
\text { ditugaskan }\end{array}$ \\
\hline
\end{tabular}

\section{Do (Lakukan)}

Karena telah direncanakan, maka tahap selanjutnya yakni melakukan. Dalam melakukan suatu rencana lakukanlah secara bertahap dari hal yang paling kecil atau mudah pada hal yang paling atas atau sulit. Dalam hal ini telah kami paparkan di atas dari rencana yang paling mudah hingga rencana yang paling sulit. 


\section{Periksa dan teliti}

Setelah hal yang direncanakan dilakukan secara bertahap, maka hal yang harus dilakukan selanjutnya adalah dengan memeriksa atau meniliti hasil yang telah didapat, contoh: pembacaan do'a bersama yang telah terealisasi. Sehingga hasil tersebut sudah sesuai dengan apa yang telah direncanakan oleh organisasi tersebut.

\section{Action}

Metode penyesuaian ini boleh saja diterapkan ataupun tidak, karena hal ini berdasarkan hasil analisis di atas. Penyesuaian berkaitan dengan standarisasi baru untuk menghindari timbulnya masalah yang sama atau menetapkan sasaran yang baru untuk perbaikan selanjutnya. Dalam hal ini dapat kita simpulkan bahwa OSIM MDNJ merencanakan agar pembacaan do'a dapat terlaksana di area lapangan SMANJ, karena hal tersebut sudah terlaksana. Maka untuk menghindari masalah yang sama dalam tahap perencanaan selanjutnya, kita harus membiasakan hal tersebut. Sehingga siswi dapat mencapaikan tujuan yang di inginkan madrasah dan OSIM tersebut.

\section{KESIMPULAN}

Penerapan TQM pada organisasi Madrasah Diniyah Nurul Jadid, telah menerapkan organisasi, ketrampilan yang dimiliki masing-masing anggota dalam tugas-tugasnya. Dalam menerapkan metode total quality manajemen dalam suatu organisasi pesantren yakni dengan 4 metode yang dikemukakan oleh seorang ilmuwan. Bahwa, agar mencapai suatu organisasi yang bermutu maka kita perlu untuk membuat rencana yang ingin dicapai oleh organisasi tersebut, seperti terlaksananya pembacaan do'a. Setelah rencana dibuat maka organisasi tersebut harus melakukan rencana tersebut untuk mengetahui bagaimana hasil dari perencenaan itu. Sehingga dapat diteliti apakah hal tersebut sesuai dengan apa yang diinginkan organisasi?. Jika telah sesuai maka penerapan metode TQM tersebut telah tercapai, dan organisasi madrasah diniyah tersebut telah menjadi suatu organisasi yang berkualitas dan bermutu. 
12 Penerapan Metode Total Quality Management (TQM) Dalam Organisasi Pesantren

\section{DAFTAR PUSTAKA}

Akbar, Mizan. 2017. Penerapan TQM

Cakrawala Pendidikan, Juni 2005, Th. XXIV, No. 2

Fattah, Nanang. 2011. Landasan Manajemen Pendidikan. Bandung: PT REMAJA ROSDAKARYA.

http//pengertian,karakteristik,metode,manfaatTQM;byMuchlisinRiadi,November 2017.

Machali, Imam., dkk. 2016. The Handbook of Education Management. Jakarta: Prenadamedia Group.

Baharun, H. Z. (2017). Manajemen Mutu Pendidikan: Ikhtiar dalam Meningkatkan Mutu Pendidikan Madrasah melalui Pendekatan Balanced Scorecard (1st ed.). Tulungagung: Akademia Pustaka. 